ISSN 1392-3196 / e-ISSN 2335-8947

Zemdirbyste-Agriculture, vol. 105, No. 3 (2018), p. 249-256

DOI 10.13080/z-a.2018.105.032

\title{
Pre-harvest LED lighting strategies for reduced nitrate contents in leafy vegetables
}

\author{
Akvilè VIRŠILE் ${ }^{1}$, Aušra BRAZAITYTE ${ }^{1}$, Julè JANKAUSKIENE ${ }^{1}$, \\ Jurga MILIAUSKIENE ${ }^{1}$, Viktorija VAŠTAKAITE ${ }^{1}$, Ingrida ODMINYTE ${ }^{2}$, \\ Algirdas NOVIČKOVAS ${ }^{3}$, Giedre SAMUOLIENE ${ }^{1}$ \\ 'Institute of Horticulture, Lithuanian Research Centre for Agriculture and Forestry \\ Kauno 30, Babtai, Kaunas distr., Lithuania \\ E-mail: a.virsile@1sdi.lt \\ ${ }^{2}$ Vytautas Magnus University \\ K. Donelaičio 58, Kaunas, Lithuania \\ ${ }^{3}$ Institute of Applied Research, Vilnius University \\ Sauletekio 9-III, Vilnius, Lithuania
}

\begin{abstract}
Short-term pre-harvest red light treatment was evaluated as a tool to reduce nitrate $\left(\mathrm{NO}_{3}\right)$ contents in leafy vegetables, cultivated under low-light conditions in a greenhouse. Corn salad (Valerianella locusta L., 'Vit'), amaranth (Amaranthus chlorostachys Willd., 'Red Army') and tatsoi (Brassica rapa var. rosularis L., 'Rozetto F1') were cultivated under low-light conditions and 1-7 days before harvest were treated with $638 \mathrm{~nm}$ red light emitting diode light. The effects of light treatment on $\mathrm{NO}_{3}$ and nitrite $\left(\mathrm{NO}_{2}\right)$ contents, reducing enzyme activities and plant photosynthetic performance of different leafy vegetable species were explored seeking for comprehensive approach for the control of $\mathrm{NO}_{3}$ metabolism. Nitrate, nitrite, total protein contents and reducing enzyme activity depend on plant species, lighting treatment duration and their interaction. A remarkable decrease in nitrates and an increase in $\mathrm{NO}_{3}$ reductase activity were observed 3 days after red light treatment. It followed by a significant increase in $\mathrm{NO}_{2}$ and protein contents in corn salad and amaranth. A medium correlation between photosynthetic rate and $\mathrm{NO}_{3}$ contents was determined for tatsoi and corn salad. A negative statistically insignificant correlation between these indicators was established for amaranth. Short-term pre-harvest red light treatment can be applied as a technological tool to reduce $\mathrm{NO}_{3}$ contents in green vegetables, cultivated under low-light conditions. The obtained results confirm the significant relationship between plant photosynthetic rate and nitrate metabolism, as well as indicate the sensitive, but differential physiological response of different vegetable species to the applied lighting.
\end{abstract}

Key words: light emitting diodes, nitrate reductase, nitrite reductase, nitrites, photosynthesis, proteins.

\section{Introduction}

Nitrate $\left(\mathrm{NO}_{3}\right)$ is classed by food safety authorities as a contaminant in fresh vegetables. $\mathrm{NO}_{3}$ itself is fairly non-toxic for humans; however, its toxic metabolites, such as nitrite $\left(\mathrm{NO}_{2}\right)$ and $\mathrm{N}$-nitroso compounds, might have deleterious effects on health (Weightman, Hudson, 2013). Therefore, European Food Safety Authority (EFSA, 2008) suggested that acceptable daily consumption of $\mathrm{NO}_{3}$ ions should not exceed $0.007 \mathrm{mg} \mathrm{kg}^{-1}$ of body weight per day. The European Commission (Commission regulation (EU) No. 1258/2011) has set maximum limits for $\mathrm{NO}_{3}$ concentrations in green vegetables, which tend to accumulate high levels of $\mathrm{NO}_{3}$. Brian and Ivy (2015) noticed that typical consumption patterns of fruits and vegetables exceeded regulatory limits for dietary nitrate and this fact calls into question the rationale behind current nitrate and nitrite regulation. The nitrate problematics is important, as current diet is rich in a wide variety of leafy vegetables species; however, the modern horticultural technologies allow controlling the nutritional value of green vegetables. Therefore, the questions of nitrate contents in green vegetables revive in "plant factories", where plants are cultivated under fully controlled environmental conditions and in greenhouses in northern regions, where green vegetables are seasonally cultivated under low natural lighting conditions.

Since long ago, nitrogen fertilization and light intensity have been identified as the major factors that

Please use the following format when citing the article:

Viršilè A., Brazaityte A., Jankauskienè J., Miliauskienė J., Vaštakaitė V., Odminytė I., Novičkovas A., Samuolienė G. 2018. Pre-harvest LED lighting strategies for reduced nitrate contents in leafy vegetables. Zemdirbyste-Agriculture, 105 (3): $249-256$ DOI $10.13080 / \mathrm{z}-\mathrm{a} .2018 .105 .032$ 
influence $\mathrm{NO}_{3}$ content in vegetables (Santamaria, 2006). Light emitting diodes (LEDs) have provided new possibilities for horticulture and research. As a result, the effects of lighting spectra on various aspects of plant metabolism, as well as on $\mathrm{NO}_{3}$ contents were analysed (Olle, Viršile, 2013; Bian et al., 2015). Red light was identified as having the highest capacity for stimulating the activity of $\mathrm{NO}_{3}$ reductase, which means that red light can effectively reduce $\mathrm{NO}_{3}$ contents in plants (Lillo, 2008; Bian et al., 2015). Other authors have reported that blue light is also beneficial for lowering $\mathrm{NO}_{3}$ contents in lettuces, as the composition of red and blue light is more favourable for plant growth and photosynthesis (OhashiKaneko et al., 2007; Qi et al., 2007; Lin et al., 2013). Bian et al. (2016) suggest that addition of green light to red and blue LEDs even enhanced the $\mathrm{NO}_{3}$ reduction effect.

Nitrate problematics also has the economic nuances, as investments in artificial lighting highly increase the costs of production. Therefore, various shortterm plant treatment strategies have been developed, seeking to reduce $\mathrm{NO}_{3}$ contents in plant tissues. The removal, reduction or replacement of inorganic nitrogen by other ions in nutrient solution (Croitoru et al., 2015) were combined with artificial lighting (Liu, Yang, 2012), or $\mathrm{NO}_{3}$ nutrition was applied depending on the level of lighting (Demšar et al., 2004). Short-term pre-harvest LED lighting exposure was proved as an efficient tool to reduce $\mathrm{NO}_{3}$ contents in lettuces (Samuolienè et al., 2009; Zhou et al., 2012; Wanlai et al., 2013) and other green vegetables (Bliznikas et al., 2012). Continuous lighting in the pre-harvest stage was applied (Wanlai et al., 2013; Bian et al., 2016), seeking to increase photosynthetic efficiency and to reduce nitrate contents (Bian et al., 2016; Nicole et al., 2016). Photosynthesis and $\mathrm{NO}_{3}$ metabolism are highly interconnected, as carbohydrates provide energy and carbon skeleton for $\mathrm{NO}_{3}$ assimilation (Bian et al., 2015) as well as share the osmoregulative functions in the cell with $\mathrm{NO}_{3}$ ions (Umar, Iqbal, 2007; Bian et al., 2016). The decrease in $\mathrm{NO}_{3}$ contents is usually accompanied by increased carbohydrate and ascorbic acid level in vegetable tissues (Samuoliene et al., 2012; Zhou et al., 2012; Wanlai et al., 2013). Additional beneficial effects of pre-harvest LED light treatment have also been identified, as increase in leaf pigmentation due to higher levels of anthocyanins (Owen, Lopez, 2015; Nicole et al., 2016), flavonoids, tocopherols (Samuoliene et al., 2012), which also results in improved antioxidant properties of vegetables. Most of the research was performed with different lettuce species; however, the effect of light exposure on $\mathrm{NO}_{3}$ metabolism is also highly dependent on plant species (Bliznikas et al., 2012), light intensity (Wanlai et al., 2013), cultivation season (Samuoliene et al., 2012; Wojciechowska et al., 2016) which affects overall internal physiological activities.

Therefore, the objective of this study was to evaluate the effects of short-term pre-harvest red LED light treatment on the $\mathrm{NO}_{3}$ and $\mathrm{NO}_{2}$ contents, reducing enzyme activities and plant photosynthetic performance of different leafy vegetable species seeking for comprehensive approach for the control of $\mathrm{NO}_{3}$ metabolism.

\section{Materials and methods}

Plant cultivation. Experiments were performed in the greenhouses of Institute of Horticulture, Lithuanian Research Centre for Agriculture and Forestry from March to April of 2015. The seeds of corn salad (Valerianella locusta L., 'Vit'), red leaf amaranth (Amaranthus chlorostachys Willd., 'Red Army') and tatsoi (Brassica rapa var. rosularis L., 'Rozetto F1') were obtained from CN Seeds Ltd., United Kingdom. Leafy vegetables were cultivated in neutralized peat substrate (Profi mix (Durpeta, Lithuania: $\mathrm{pH}$ 6-6.5; N $115 \mathrm{mg} \mathrm{L} \mathrm{L}^{-1}, \mathrm{P}_{2} \mathrm{O}_{5}$ $55 \mathrm{mg} \mathrm{L}^{-1}, \mathrm{~K}_{2} \mathrm{O} 160 \mathrm{mg} \mathrm{L}^{-1}$ with microelements $\mathrm{Fe}, \mathrm{Mn}^{5}$, $\mathrm{Cu}, \mathrm{B}, \mathrm{Mo}$ and $\mathrm{Zn}$ ) in plastic trays of $70 \mathrm{ml}$ cell volume, three plants per cell. Equal soil humidity was maintained, once a week plants were fertilized with $0.2 \%$ ammonium nitrate $\left(\mathrm{NO}_{3}\right)$ solution. During experiments, $\sim 18 \pm 2 / 22$ $\pm 2{ }^{\circ} \mathrm{C}$ night/day temperature was maintained, relative air humidity was $55-70 \%$. Average daily photosynthetic photon flux density (PPFD) of natural lighting in the greenhouse varied between $170-250 \mu \mathrm{mol} \mathrm{m} \mathrm{m}^{-2} \mathrm{~s}^{-1}$.

Red light emitting diode (LED) treatment. Null (reference), 1, 3, 5 and 7 days before harvesting corn salad, tatsoi and amaranth were supplementary illuminated with an originally designed red light emitting diodes (LEDs) lighting unit (Bliznikas et al., 2009; Žukauskas et al., 2012). The unit was designed seeking to minimize radial heat emission at high light intensities, therefore it can be placed close to the plants $(\sim 30 \mathrm{~cm}$ above). The lighting unit consists of $638 \mathrm{~nm}$ LEDs LUXEON III Star, model LXHL-LD3C (Philips LLC, USA), that creates $300 \mu \mathrm{mol} \mathrm{m} \mathrm{m}^{-2} \mathrm{~s}^{-1}$ PPFD and illuminates $3.5 \mathrm{~m}^{2}$ area at $16 \mathrm{~h}$ photoperiod. Trays with plants were transferred under investigated lighting unit (4 trays per treatment, 72 plants per tray) in a randomized order. Each tray was treated as the replication of the treatment. Plants were harvested at baby leaf stage, when 5-6 leaves had formed: tatsoi was grown for 21 days, corn salad and amaranth for 25 days from sowing. After lighting exposure, photosynthetic and biochemical parameters were evaluated. The first fully developed leaves of randomly selected plants from each LED light treatment were used for biochemical analysis and measurements.

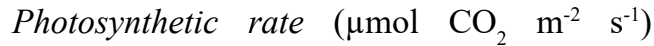
was measured using the LI-6400XT (LI-COR, USA) photosynthesis system on the first fully matured leaf. The instrument was set for $400 \mu \mathrm{mol} \mathrm{s}{ }^{-1}$ airflow, $25^{\circ} \mathrm{C}$ cell temperature, $400 \mu \mathrm{mol} \mathrm{CO} \mathrm{mol}^{-1}, 60 \%$ relative humidity in the cell and light intensity of $200 \mu \mathrm{mol} \mathrm{m}^{-2} \mathrm{~s}^{-1}$.

Chlorophyll and flavonol indexes were measured in the first fully matured leaf using Dualex meter (Dynamax, USA), 10 plants per treatment.

For biochemical analysis, the leaves from each light treatment were combined in single conjugated biological sample and three analytical replications were performed for each measurement. Total protein contents and $\mathrm{NO}_{3}$ reductase activity were determined in fresh plant matter. For $\mathrm{NO}_{3}$ analysis, plant material was dried at $70^{\circ} \mathrm{C}$ for $48 \mathrm{~h}$. All data are expressed on a fresh weight (FW) basis.

Nitrate $\left(\mathrm{NO}_{3}\right)$ and nitrite $\left(\mathrm{NO}_{2}\right)$ contents were determined by spectrophotometric method. Samples were prepared by hot water $\left(70^{\circ} \mathrm{C}, 1: 100 \mathrm{w}: \mathrm{w}\right)$ extraction 
from dry plant material in ultrasonic bath for $30 \mathrm{~min}$. Initial $\mathrm{NO}_{2}$ concentration and total $\mathrm{NO}_{2}$ after zinc reduction were determined by diazotization-coupling Griess reaction (Merino, 2009) at $540 \mathrm{~nm}$. $\mathrm{NO}_{3}$ and $\mathrm{NO}_{2}$ contents $\left(\mathrm{mg} \mathrm{kg}{ }^{-1}\right)$ were determined according to the calibration curve and expressed on the FW basis.

Total protein contents were determined according to Bradford (1976) method. The fresh material was ground with liquid nitrogen and extracted with $50 \mathrm{mM}$ phosphate buffer solution with $1 \mathrm{mM}$ ethylenediaminetetraacetic acid (EDTA), $10 \mathrm{mM}$ 2-merkaptoethanol, $\quad 100 \mu \mathrm{M}$ phenylmethylsulfonyl fluoride (PMSF). Homogenate was centrifuged for $10 \mathrm{~min} 4000 \mathrm{rpm} \mathrm{min}^{-1}$ and used for total protein content and enzyme activity determination. The sample was mixed with diluted Bradford reagent and absorbance at $595 \mathrm{~nm}$ was measured. Total protein contents $\left(\mathrm{mg} \mathrm{g}^{-1}\right.$ in FW) were determined according to the bovine serum albumin (BSA) calibration curve.

Nitrate reductase (NR) activity was determined by mixing $0.1 \mathrm{ml}$ of protein extract with assay mix, containing $25 \mathrm{mM}$ phosphate buffer $(\mathrm{pH} 7.3), 10 \mathrm{mM}$ potassium nitrate $\left(\mathrm{KNO}_{3}\right)$ and $0.5 \mathrm{mM}$ EDTA, and adding $2.0 \mathrm{mM} \beta$-nicotinamide adenine dinucleotide $(\beta-\mathrm{NADH})$, total volume of $2 \mathrm{ml}$. After incubation at $30^{\circ} \mathrm{C}$ for $5 \mathrm{~min}$, reaction was stopped with $1 \mathrm{ml}$ of $1 \%$ sulfanilamide in $3 \mathrm{~N}$ $\mathrm{HCl}$ and $1 \mathrm{ml}$ of $0.02 \% \mathrm{~N}$-(1-naphthyl)-ethylenediamine dihydrochloride. After $10 \mathrm{~min}$ incubation in room temperature the absorption was measured at $540 \mathrm{~nm}$ and the contents of $\mathrm{NO}_{2}$ formed were determined according to a calibration curve of standard sodium nitrite solutions. Enzyme activity was evaluated as an amount of $\mathrm{NO}_{2}$ ions formed per hour $\left(\mu \mathrm{mol} \mathrm{NO} \mathrm{g}^{-1} \mathrm{~h}^{-1}\right)$.

Nitrite $\left(\mathrm{NO}_{2}\right)$ reductase (NiR) activity was determined (Takahashi et al., 2001) by mixing protein extract with $50 \mathrm{mM}$ phosphate buffer $(\mathrm{pH} 7.5), 1 \mathrm{mM}$ sodium nitrite $\left(\mathrm{NaNO}_{2}\right)$ and $1 \mathrm{mM}$ methyl viologen. Reaction was initiated by adding $57.4 \mathrm{mM}$ sodium dithionite $\left(\mathrm{Na}_{2} \mathrm{~S}_{2} \mathrm{O}_{4}\right)$ in $290 \mathrm{mM}$ sodium bicarbonate $\left(\mathrm{NaHCO}_{3}\right)$ solution. After $5 \mathrm{~min}$ incubation at $30^{\circ} \mathrm{C}$ temperature, $20 \mu \mathrm{l}$ of reaction mixture was transferred to new vial, containing $480 \mu \mathrm{l}$ of water and vortexed. Immediately, $500 \mu 11 \%$ sulfanilamide in $3 \mathrm{~N} \mathrm{HCl}$ and $500 \mu \mathrm{l} 0.02 \%$ $\mathrm{N}$-(1-naphthyl)-ethylenediamine dihydrochloride were added. After $10 \mathrm{~min}$ absorption was measured at $540 \mathrm{~nm}$. Enzyme activity was expressed as the amount of $\mathrm{NO}_{2}$ ions formed per hour ( $\left.\mu \mathrm{mol} \mathrm{NO}_{2} \mathrm{~g}^{-1} \mathrm{~h}^{-1}\right)$.

Statistical analysis. Values are presented as mean \pm standard deviation in fresh weight $(\mathrm{FW})$. For data evaluation the Student's $t$-test and determination coefficients (simple linear regression) at $p<0.05$ were used (Raudonius, 2017). Softwares MS Excel, version 7.0, and Statistica, version 7.0 were used for data processing.

\section{Results and discussion}

Artificial lighting with $638 \mathrm{~nm}$ red LEDs, applied for 1-7 days before harvesting can help reduce energy costs for plant cultivation in commercial greenhouses, compared to conventional lighting during the whole cultivation cycle. The effect of applied lighting was dependant on plant species and duration of lighting exposure (Fig.). A 3-day pre-harvest lighting reduced
$\mathrm{NO}_{3}$ contents in corn salad, amaranth and tatsoi by $2.1,8.1$ and 2.2 times, respectively, as compared to the reference non-illuminated plants.

Strong negative correlation was determined between lighting duration and $\mathrm{NO}_{3}$ contents in amaranth and tatsoi $(R=-0.7962$ and $R=-0.8021$ respectively, $p \leq 0.05$ ). Corn salad adapted to high PPFD red light and illuminating more than 3 days, no further $\mathrm{NO}_{3}$ reduction was observed (Fig. A). The decrease in $\mathrm{NO}_{3}$ contents after 3 days of lighting was followed by the increase in $\mathrm{NO}_{2}$ contents. $\mathrm{NO}_{2}$ contents (Fig. D-F) after 3 days of red light treatment were by $4.8,1.8$ and 1.7 times higher in corn salad, amaranth and tatsoi, respectively. However, no direct correlation between $\mathrm{NO}_{3}$ and $\mathrm{NO}_{2}$ contents was determined when illuminating plants with red light for 1-7 days. Burns et al. (2011), analysing the genotype and environment effects on $\mathrm{NO}_{3}$ assimilation processes, concluded that variability in $\mathrm{NO}_{3}$ accumulation under different environmental conditions arises more from differences in uptake of nitrate than from differences in efficiency of its chemical reduction. However, the changes in $\mathrm{NO}_{3}$ and $\mathrm{NO}_{2}$ contents and enzymatic activity during 1-7 days of light exposure indicate an important direct and indirect role of light on $\mathrm{NO}_{3}$ metabolism. The remarkable increase in $\mathrm{NO}_{2}$ contents suggests the need for more detailed analysis of this contaminant in green leafy vegetables. After analysis of numerous lettuce and spinach samples Iammarino et al. (2014) have also raised the idea about determining maximum admissible level for nitrites in leafy vegetables, as high $\mathrm{NO}_{2}$ contents do not necessarily correlate with high levels or $\mathrm{NO}_{3}$.

The reduction of $\mathrm{NO}_{3}$ ions occurs in two step processes. $\mathrm{NO}_{3}$ is first reduced by cytosolic nitrate reductase (NR) to $\mathrm{NO}_{2}$, which is then imported into the chloroplast and reduced further by nitrite reductase (NiR) into ammonium (Krapp, 2015). NR is considered as the key enzyme in this process (Wojciechowska et al., 2016). The obtained results show that NR and NiR activities are regulated independently. $\mathrm{NO}_{3}, \mathrm{NO}_{2}$, total protein contents and reducing enzyme activity depend on plant species, lighting treatment duration and their interaction (Tables 1 and 2). Short-term red LED light treatment enhanced NR activity. The highest enzyme activity was determined after 5-7 days of supplemental red LED light exposure in amaranth and tatsoi. NR activity in amaranth increased 1.79 times after 5 days of lighting, in tatsoi - 1.70 times after 7 days of illumination. NiR activity was also determined the highest after 5 days in amaranth and after 7 days in tatsoi; it was increased 1.67 and 2.06 times, respectively, as compared to non-illuminated plants. In corn salad, NR activity changed insignificantly; NiR activity was determined lower, as compared to nonilluminated plants.

The analysis of total protein contents showed that lighting duration had statistically significant effect. The most pronounced effect was determined in corn salad after 5 days and in amaranth after 7 days' illumination with red LED light. Protein contents increased 1.54 and 1.34 times, as compared to the reference. The increase in protein contents did not correlate with $\mathrm{NO}_{3}$ contents 

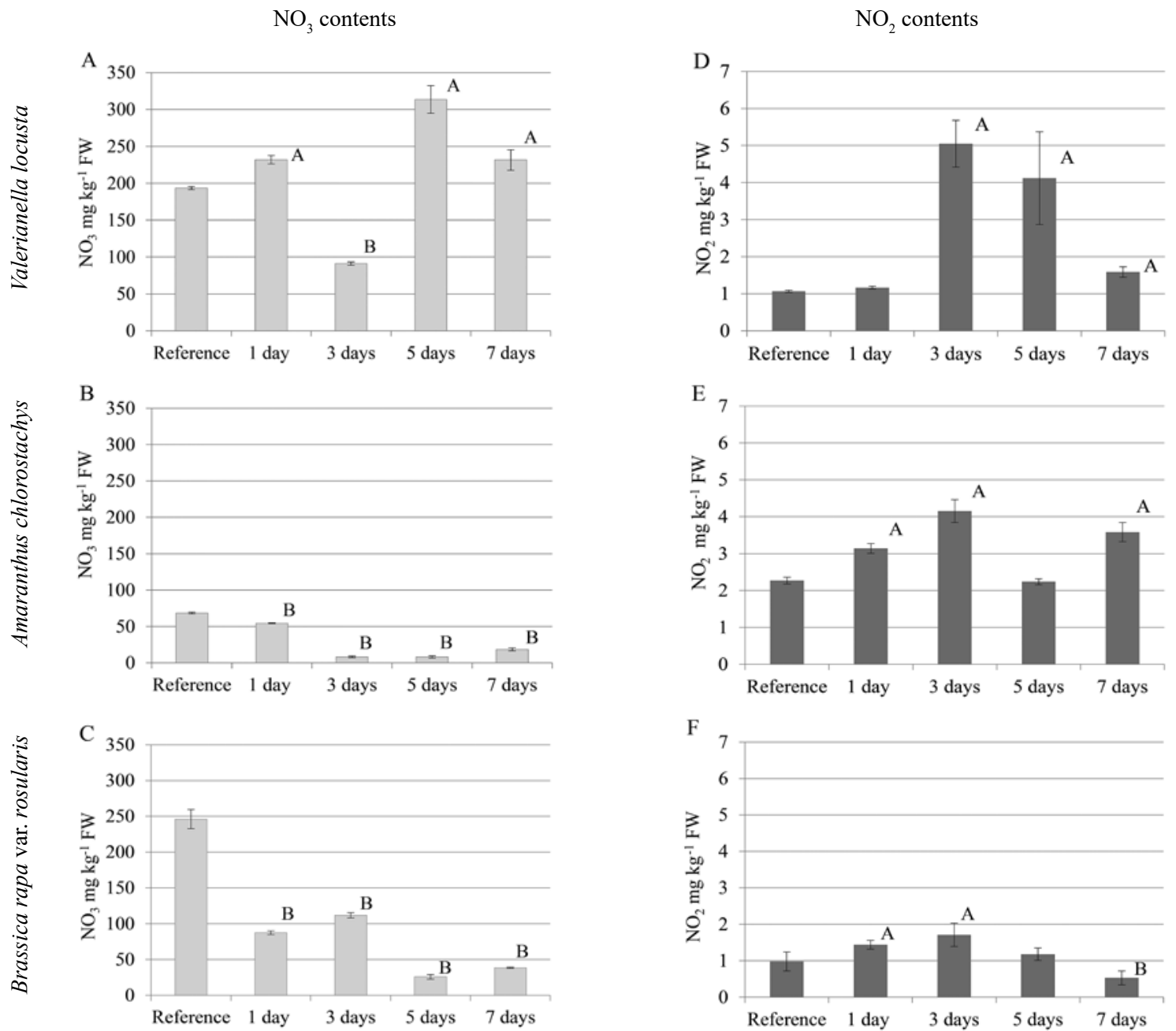

Note. A - value significantly higher, B - value significantly lower than reference (non-illuminated plants) according to Student's $t$-test, $p \leq 0.05$; each data point represents mean \pm standard deviation, $\mathrm{n}=3$.

Figure. The effect of 1-7 days' pre-harvest red light emitting diode (LED) treatment on nitrate $\left(\mathrm{NO}_{3}\right)$ and nitrite $\left(\mathrm{NO}_{2}\right)$ contents in leafy vegetables

Table 1. Nitrate reductase (NR), nitrite reductase (NiR) activities and total protein contents in leafy vegetables after 1-7 days' pre-harvest red LED lighting treatment

\begin{tabular}{ccccc}
\hline & $\begin{array}{c}\text { Duration of } \\
\text { red light exposure }\end{array}$ & $\begin{array}{c}\text { Valerianella } \\
\text { locusta }\end{array}$ & $\begin{array}{c}\text { Amaranthus } \\
\text { chlorostachys }\end{array}$ & $\begin{array}{c}\text { Brassica rapa } \\
\text { var. rosularis }\end{array}$ \\
\hline $\mathrm{NR}$ & reference & $5.23 \pm 0.46$ & $8.88 \pm 0.34$ & $5.87 \pm 0.15$ \\
$\mu \mathrm{mol} \mathrm{NO} \mathrm{g}^{-1} \mathrm{~h}^{-1}$ & 1 day & $5.49 \pm 0.10$ & $10.28 \pm 0.56 \mathrm{~A}$ & $8.97 \pm 1.41 \mathrm{~A}$ \\
& 3 days & $3.98 \pm 0.09 \mathrm{~B}$ & $9.61 \pm 0.87$ & $7.33 \pm 0.78 \mathrm{~A}$ \\
& 5 days & $6.79 \pm 0.24 \mathrm{~A}$ & $15.79 \pm 0.62 \mathrm{~A}$ & $6.38 \pm 0.15 \mathrm{~A}$ \\
& 7 days & $4.37 \pm 0.50 \mathrm{~B}$ & $12.31 \pm 0.26 \mathrm{~A}$ & $10.00 \pm 1.53 \mathrm{~A}$ \\
\hline $\mathrm{NiR}$ & reference & $23.26 \pm 1.23$ & $27.12 \pm 1.44$ & $8.21 \pm 0.44$ \\
& 1 day & $18.14 \pm 1.02 \mathrm{~B}$ & $15.18 \pm 0.85 \mathrm{~B}$ & $3.76 \pm 0.12 \mathrm{~B}$ \\
& 3 days & $20.53 \pm 1.11 \mathrm{~B}$ & $15.79 \pm 0.93 \mathrm{~B}$ & $3.63 \pm 0.20 \mathrm{~B}$ \\
$\mathrm{Tmol} \mathrm{NO}_{2} \mathrm{~g}^{-1} \mathrm{~h}^{-1}$ & 5 days & $11.78 \pm 0.68 \mathrm{~B}$ & $45.27 \pm 2.63 \mathrm{~A}$ & $14.67 \pm 0.85 \mathrm{~A}$ \\
& 7 days & $20.51 \pm 1.23 \mathrm{~B}$ & $35.28 \pm 2.22 \mathrm{~A}$ & $16.95 \pm 1.02 \mathrm{~A}$ \\
\hline $\mathrm{mg} \mathrm{kg}^{-1}$ & reference & $1.45 \pm 0.13$ & $5.14 \pm 0.13$ & $6.14 \pm 0.02$ \\
& 1 day & $2.30 \pm 0.09 \mathrm{~A}$ & $6.74 \pm 0.35 \mathrm{~A}$ & $3.76 \pm 0.12 \mathrm{~B}$ \\
& 3 days & $2.09 \pm 0.15 \mathrm{~A}$ & $6.04 \pm 0.33 \mathrm{~A}$ & $6.14 \pm 0.05$ \\
& 5 days & $2.24 \pm 0.15 \mathrm{~A}$ & $6.66 \pm 0.22 \mathrm{~A}$ & $4.93 \pm 0.16 \mathrm{~B}$ \\
\hline
\end{tabular}

Note. A - value significantly higher, B - value significantly lower than reference (non-illuminated plants) according to Student's $t$-test, $p \leq 0.05$; each data point represents mean \pm standard deviation, $\mathrm{n}=3$. 
Table 2. Determination coefficient $R$ between nitrate reductase (NR), nitrite reductase (NiR), nitrate, nitrite and protein contents in leafy vegetables

\begin{tabular}{cccc}
\hline \multicolumn{4}{c}{ Valerianella locusta } \\
\hline \multirow{4}{*}{ total proteins } & nitrites & nitrates \\
\cline { 2 - 4 } NiR & 0.3229 & 0.0023 & 0.8268 \\
Nitrates & $-0.7019^{*}$ & -0.4095 & $-0.6968^{*}$ \\
Nitrites & 0.1710 & -0.2448 & - \\
\hline \multicolumn{4}{c}{ Amaranthus chlorostachys } \\
\hline NR & total proteins & nitrites & nitrates \\
\cline { 2 - 4 } NiR & $0.5674^{*}$ & -0.3250 & $-0.6075^{*}$ \\
Nitrates & 0.2379 & $-0.5471^{*}$ & -0.3740 \\
Nitrites & -0.5057 & -0.4201 & - \\
\hline \multicolumn{5}{c}{0.2399} & - & - \\
\hline Brassica rapa var. rosularis \\
NR & total proteins & nitrites & nitrates \\
\cline { 2 - 4 } NiR & $-0.7221^{*}$ & -0.2995 & -0.4750 \\
Nitrates & -0.3951 & $-0.7529^{*}$ & -0.4886 \\
Nitrites & 0.6598 & 0.0676 & - \\
\hline$-p \leq 0.05$ & 0.3473 & - & - \\
\hline \multicolumn{4}{c}{}
\end{tabular}

in plant tissues. However, strong negative correlation was determined between total protein content and NiR in corn salad and NR in tatsoi (Table 2). In amaranth, positive correlation between NR activity and total protein contents was determined. Liu et al. (2016) analysed primary metabolism of $\mathrm{NO}_{3}$ in lettuce, cultivated under different light sources, and proposed that wide spectrum lamps, such as fluorescent, determined the lowest $\mathrm{NO}_{3}$ contents in lettuce tissues, but stimulated uptake of $\mathrm{NO}_{3}$ from soil and protein synthesis, when red and blue LED light inhibited protein synthesis. These trends, as well as obtained results confirm the differential response of plant species and varieties to light exposures. $\mathrm{NO}_{3}$ reduction upon light treatments was more efficient in species naturally containing higher concentrations of antioxidant phenols, anthocyanins (Samuoliene et al., 2011; Bliznikas et al., 2012), as pre-harvest changes in lighting conditions require plant adaptation and might evoke photostress conditions.

The photosynthetic parameters (Table 3) are also affected by pre-harvest red LED light treatment.

Medium correlation between photosynthetic rate and $\mathrm{NO}_{3}$ contents was determined in tatsoi and corn salad. A negative statistically insignificant correlation

Table 3. Photosynthetic rate, chlorophyll and flavonol indexes in leafy vegetables after 1-7 days' pre-harvest treatment with red $638 \mathrm{~nm}$ light

\begin{tabular}{ccccc}
\hline & $\begin{array}{c}\text { Duration of } \\
\text { red light exposure }\end{array}$ & $\begin{array}{c}\text { Valerianella } \\
\text { locusta }\end{array}$ & $\begin{array}{c}\text { Amaranthus } \\
\text { chlorostachys }\end{array}$ & $\begin{array}{c}\text { Brassica rapa } \\
\text { var. rosularis }\end{array}$ \\
\hline Reference & $11.80 \pm 1.63$ & $2.54 \pm 1.15$ & $4.65 \pm 0.50$ \\
Photosynthetic rate $_{\mu \text { mol } \mathrm{CO}_{2} \mathrm{~m}^{-2} \cdot \mathrm{s}^{-1}}$ & 1 day & $12.56 \pm 1.46$ & $7.21 \pm 3.50$ & $4.13 \pm 0.64$ \\
& 3 days & $11.40 \pm 1.14$ & $9.44 \pm 3.67 \mathrm{~A}$ & $2.86 \pm 0.28 \mathrm{~B}$ \\
& 5 days & $13.71 \pm 0.54$ & $7.44 \pm 3.79$ & $3.22 \pm 0.98$ \\
& 7 days & $13.91 \pm 1.41$ & $5.61 \pm 0.96 \mathrm{~A}$ & $2.74 \pm 0.20 \mathrm{~B}$ \\
\hline Reference & $36.72 \pm 0.48$ & $21.90 \pm 0.38$ & $36.94 \pm 2.24$ \\
& 1 day & $26.97 \pm 0.59$ & $36.18 \pm 1.06 \mathrm{~A}$ & $35.04 \pm 2.64$ \\
& 3 days & $29.46 \pm 0.91 \mathrm{~B}$ & $25.78 \pm 1.81 \mathrm{~A}$ & $36.12 \pm 2.54$ \\
& 5 days & $29.63 \pm 1.83 \mathrm{~B}$ & $24.75 \pm 0.82 \mathrm{~A}$ & $35.64 \pm 2.43$ \\
& 7 days & $33.53 \pm 3.95 \mathrm{~B}$ & $20.38 \pm 0.91 \mathrm{~B}$ & $27.80 \pm 3.55 \mathrm{~B}$ \\
\hline Flavonol index & Reference & $0.34 \pm 0.03$ & $0.18 \pm 0.01$ & $0.61 \pm 0.03$ \\
& 1 day & $0.33 \pm 0.03$ & $0.19 \pm 0.03$ & $0.71 \pm 0.09$ \\
& 3 days & $0.39 \pm 0.01$ & $0.26 \pm 0.05 \mathrm{~A}$ & $0.84 \pm 0.06 \mathrm{~A}$ \\
& 5 days & $0.39 \pm 0.06$ & $0.23 \pm 0.02 \mathrm{~A}$ & $0.94 \pm 0.04 \mathrm{~A}$ \\
\hline
\end{tabular}

Note. A - value significantly higher, B - value significantly lower than reference (non-illuminated plants) according to Student's $t$-test, $p \leq 0.05$; each data point represents mean \pm standard deviation, $\mathrm{n}=3$.

between these indicators was established for amaranth (Table 4). In corn salad, no statistically significant differences in photosynthetic rate were observed. In amaranth, photosynthesis was remarkably higher after 1-3 days of red LED treatment (photosynthetic rate was 3.7 times higher, as compared to non-illuminated plants). Further lighting (5-7 days) resulted in slight decrease in photosynthetic rate, but it was still higher, as compared to the reference. In tatsoi, photosynthetic rate was negatively affected by pre-harvest light treatment. No direct correlation between photosynthetic rate and chlorophyll
Table 4. Determination coefficient between nitrates and photosynthetic rate in leafy vegetables

\begin{tabular}{llll}
\hline & $\begin{array}{c}\text { Valerianella } \\
\text { locusta }\end{array}$ & $\begin{array}{c}\text { Amaranthus } \\
\text { chlorostachys }\end{array}$ & $\begin{array}{c}\text { Brassica } \\
\text { rapa var. } \\
\text { rosularis }\end{array}$ \\
\hline & nitrates & \\
\hline $\begin{array}{c}\text { Photosynthesis } \\
\text { intensity }\end{array}$ & $0.5696^{*}$ & -0.5117 & $0.6324^{*}$ \\
\hline$*_{-p} \leq 0.05$ & & &
\end{tabular}


content was observed, as the changes in chlorophyll content are the result of longer-term exposure, when photosynthetic rate changes immediately under different lighting conditions. In corn salad chlorophyll index decreased with the duration of pre-harvest light exposure. In amaranth, chlorophyll index increased during the first days of treatment, but significantly decreased after 7 days' exposure. In tatsoi, remarkable decrease in chlorophyll index was determined after 7 days' exposure.

The increase in flavonol index in leaves reflects plant adaptation to unfavourable conditions. High PPFD flux of red light can act as a photostressor for plants and evoke the response of antioxidant system (Petrussa et al., 2013). Strong positive correlation $(R=0.73-0.93)$ was determined between flavonol index and lighting duration in all green vegetables, which shows active adaptation processes.

\section{Conclusions}

1. Short-term pre-harvest red light treatment can be applied as a technological tool to reduce nitrate $\left(\mathrm{NO}_{3}\right)$ contents in leafy vegetables, cultivated under low natural light conditions.

2. The obtained results show a close interrelation between $\mathrm{NO}_{3}$ metabolism and photosynthesis parameters under light treatments, but no single trend was determined in all vegetable species. The higher photosynthetic photon flux density (PPFD) lighting, applied on mature plants before harvesting, evoked the adaptation processes and the response of antioxidant system and might act as a photostressor for more sensitive vegetable species.

3. The effect of light on $\mathrm{NO}_{3}$ reduction is closely linked to overall plant light sensitivity and internal physiological activities. In corn salad (Valerianella locusta L.), the applied lighting had no remarkable effect on photosynthetic rate and enzyme activity, thus the $\mathrm{NO}_{3}$ reduction was observed only after 3 days of lighting and further increased, as plants adapted to the applied lighting. In amaranth (Amaranthus chlorostachys Willd.) and tatsoi (Brassica rapa var. rosularis L.), nitrate reductase activity was promoted under red LED lighting and remarkable $\mathrm{NO}_{3}$ reduction was observed.

4. The correlation between the photosynthetic rate and $\mathrm{NO}_{3}$ contents in all plants confirm the significant interrelation between photosynthesis and $\mathrm{NO}_{3}$ metabolism; however, the differential response of the vegetables species to the applied lighting was also indicated.

5. Further comprehensive research is necessary to evaluate species and variety specific effects of the red light treatment on nitrate content reduction in different green vegetables.

\section{Acknowledgements}

The research was funded by a grant MIP60/2015 from the Research Council of Lithuania.

Received 16012018 Accepted 29052018

\section{References}

1. Bian Z. H., Yang Q. C., Liu W. K. 2015. Effects of light quality on the accumulation of phytochemicals in vegetables produced in controlled environments: a review. Journal of the Science of Food and Agriculture, 95: 869-877.

https://doi.org/10.1002/jsfa.6789

2. Bian Z. H., Cheng R. F., Yang Q. C., Wang J., Lu C. 2016. Continuous light from red, blue, and green lightemitting diodes reduces nitrate content and enhances phytochemical concentrations and antioxidant capacity in lettuce. Journal of the American Society for Horticultural Science, 141 (2): 186-195.

3. Bliznikas Z., Breivè K., Novičkovas A., Vitta P., Žukauskas A., Duchovskis P. 2009. Solid-state lamp for the improvement of nutritional quality of leafy vegetables. Electronics and Electrical Engineering, 8: 47-50.

4. Bliznikas Z., Zukauskas A., Samuolienė G., Viršilè A., Brazaitytė A., Jankauskienè J., Duchovskis P., Novičkovas A. 2012. Effect of supplementary pre-harvest LED lighting on the antioxidant and nutritional properties of green vegetables. Acta Horticulturae, 939: 85-91. https://doi.org/10.17660/ActaHortic.2012.939.10

5. Bradford M. M. 1976. A rapid and sensitive for the quantitation of microgram quantities of protein utilizing the principle of protein-dye binding. Analytical Biochemistry, 72: $248-254$.

https://doi.org/10.1016/0003-2697(76)90527-3

6. Brian N. S., Ivy J. L. 2015. Inorganic nitrite and nitrate: evidence to support consideration as dietary nutrients. Nutrition Research, 35: 643-654. https://doi.org/10.1016/j.nutres.2015.06.001

7. Burns I. G., Zhang K., Turner M. K., Lynn J., McClement S., Hand P., Pink D. 2011. Genotype and environment effects on nitrate accumulation in a diversity set of lettuce accessions at commercial maturity: the influence of nitrate uptake and assimilation, osmotic interactions and shoot weight and development. Journal of the Science of Food and Agriculture, 91: 2217-2233.

https://doi.org/10.1002/jsfa.4442

8. Commission regulation (EU) No. $1258 / 2011$ of 2 December 2011 amending Regulation(EC) No. 1881/2006 as regards maximum levels for nitrates in foodstuffs. http://data.europa.eu/eli/reg/2011/1258/oj

9. Croitoru M. D., Muntean D. L., Fülöp I., Modroiu A. 2015. Growing patterns to produce 'nitrate free' lettuce (Lactuca sativa). Food Additives and Contaminants: Part A, 32: 80-86. https://doi.org/10.1080/19440049.2014.979887

10. Demšar J., Osvald J., Vodnik D. 2004. The Effect of light-dependent application of nitrate on the growth of aeroponically grown lettuce (Lactuca sativa L.). Journal of the American Society for Agricultural Sciences, 129 (4): 570-575.

11. EFSA. 2008. Nitrate in vegetables. Scientific opinion of the panel on contaminants in the food chain. The EFSA Journal, 689: 1-79.

12. Iammarino M., Di Taranto A., Cristino M. 2014. Monitoring of nitrites and nitrates levels in leafy vegetables (spinach and lettuce): a contribution to risk assessment. Journal of the Science of Food and Agriculture, 94: 773-778. https://doi.org/10.1002/jsfa.6439

13. Krapp A. 2015. Plant nitrogen assimilation and its regulation: a complex puzzle with missing pieces. Current Opinion in Plant Biology, 25: 115-122. https://doi.org/10.1016/j.pbi.2015.05.010 
14. Lillo C. 2008. Signalling cascades integrating lightenhanced nitrate metabolism. Biochemical Journal, 415:1 1-19. https://doi.org/10.1042/BJ20081115

15. Lin K. H., Huang M. Y., Huang W. D., Hsu M. H., Yang Z. W., Yang C. M. 2013. The effects of red, blue, and white light-emitting diodes on the growth, development, and edible quality of hydroponically grown lettuce (Lactuca sativa L. var. capitata). Scientia Horticulturae, 150: 86-91. https://doi.org/10.1016/j.scienta.2012.10.002

16. Liu H., Fu Y., Yu J., Liu H. 2016. Accumulation and primary metabolism of nitrate in lettuce (Lactuca sativa $\mathrm{L}$. var. youmaicai) grown under three different light sources. Communications in Soil Science and Plant Analysis, 47:1994-2002. https://doi.org/10.1080/00103624.2016.1225076

17. Liu W. K., Yang Q. C. 2012. Effects of short-term treatment with various light intensities and hydroponic solutions on nitrate concentration of lettuce. Acta Agriculturae Scandinavica, Section B: Soil and Plant Science, 62: 109-113.

18. Merino L. 2009. Development and validation of a method for determination of residual nitrite/nitrate in foodstuffs and water after zinc reduction. Food Analytical Methods, 2: $212-220$. https://doi.org/10.1007/s12161-008-9052-1

19. Nicole C. C. S., Charalambous F., Martinakos S., van de Voort S., Li Z., Verhoog M., Krijn M. 2016. Lettuce growth and quality optimization in plant factory. Acta Horticulturae, 1134: 231-238. https://doi.org/10.17660/ActaHortic.2016.1134.31

20. Ohashi-Kaneko K., Takase M., Kon N., Fujiwara K., Kurata K. 2007. Effect of light quality on growth and vegetable quality in leaf lettuce, spinach and komatsuna. Environmental Control in Biology, 45: 189-198. https://doi.org/10.2525/ecb.45.189

21. Olle M., Viršile A. 2013. The effects of light-emitting diode lighting on greenhouse plant growth and quality. Agricultural and Food Science, 22: 223-234.

22. Owen W. G., Lopez R. G. 2015. End-of-production supplemental lighting with red and blue light-emitting diodes (LEDs) influences red pigmentation of four lettuce varieties. HortScience, 50 (5): 676-684.

23. Petrussa E., Braidot E., Zancani M., Peresson C., Bertolini A., Patui S., Vianello V. 2013. Plant flavonoids - biosynthesis, transport and involvement in stress responses. International Journal of Molecular Sciences, 14 (7): 14950-14973.

https://doi.org/10.3390/ijms140714950

24. Raudonius S. 2017. Application of statistics in plant and crop research: important issues. Zemdirbyste-Agriculture, 104 (4): p. 377-382. https://doi.org/10.13080/z-a.2017.104.048

25. Qi L. D., Liu S. H. Q., Xu L., Yu W. Y., Lang Q. L., Hao S. H. Q. 2007. Effects of light qualities on accumulation of oxalate, tannin and nitrate in spinach. Transactions of the Chinese Society of Agricultural Engineering, 4: 201-205.

26. Samuolienè G., Urbonavičiūte A., Duchovskis P., Bliznikas Z., Vitta P., Žukauskas A. 2009. Decrease in nitrate concentration in leafy vegetables under a solid-state illuminator. HortScience, 44 (7): 1857-1860.

27. Samuoliene G., Brazaitytė A., Sirtautas R., Novičkovas A., Duchovskis P. 2011. Supplementary red-LED lighting affects phytochemicals and nitrate of baby leaf lettuce. Journal of Food, Agriculture and Environment, 9 (3-4): 271-274.
28. Samuoliene G., Sirtautas R., Brazaityte A., Virsile A., Duchovskis P. 2012. Supplementary red-LED lighting and the changes in phytochemical content of two baby leaf lettuce varieties during three seasons. Journal of Food, Agriculture and Environment, 10 (3-4): 701-706.

29. Samuolienè G., Brazaitytė A., Sirtautas R., Novičkovas A., Duchovskis P. 2012. The effect of supplementary LED lighting on antioxidant and nutritional properties of lettuce. Acta Horticulturae, 952: 835-841. https://doi.org/10.17660/ActaHortic.2012.952.106

30. Santamaria P. 2006. Nitrate in vegetables: toxicity, content, intake and EC regulation. Journal of the Science of Food and Agriculture, 86: 10-17. https://doi.org/10.1002/jsfa.2351

31. Takahashi M., Sasaki Y., Ida S., Morikawa H. 2001. Nitrite reductase gene enrichment improves assimilation of $\mathrm{NO}_{2}$ in Arabidopsis. Plant Physiology, 126: 731-741. https://doi.org/10.1104/pp.126.2.731

32. Umar A. S., Iqbal M. 2007. Nitrate accumulation in plants, factors affecting the process, and human health implications. Agronomy for Sustainable Development, 27 ( 1): 45-57. https://doi.org/10.1051/agro:2006021

33. Wanlai Z., Liu W., Qichang Y. 2013. Reducing nitrate content in lettuce by pre-harvest continuous light delivered by red and blue light emitting diodes. Journal of Plant Nutrition, 36: 481-490. https://doi.org/10.1080/01904167.2012.748069

34. Weightman R. M., Hudson M. 2013. Noxious or nutritious? Progress in controlling nitrate as a contaminant in leafy crop species. Food and Energy Security, 2: 141-156. https://doi.org/10.1002/fes3.28

35. Wojciechowska R., Kołton A., Długosz-Grochowska O., Knop E. 2016. Nitrate content in Valerianella locusta L. plants is affected by supplemental LED lighting. Scientia Horticulturae, 211: 179-186. https://doi.org/10.1016/j.scienta.2016.08.021

36. Zhou W. L., Liu W. K., Yang Q. C. 2012. Quality changes in hydroponic lettuce grown under pre-harvest short-duration continuous light of different intensities. The Journal of Horticultural Science and Biotechnology, 87 (5): 429-434. https://doi.org/10.1080/14620316.2012.11512890

37. Žukauskas A., Duchovskis P., Bliznikas Z., Samuolienė G., Urbonavičiute A., Vitta P. 2012. Method and apparatus for the reduction of harmful nitrates in plants using radiant flux generated by a solid-state illuminator. European Patent $12 / 21$ of 23.05 .122111097 B1. 
ISSN 1392-3196 / e-ISSN 2335-8947

Zemdirbyste-Agriculture, vol. 105, No. 3 (2018), p. 249-256

DOI $10.13080 /$ z-a.2018.105.032

\title{
LED apšvietimo taikymas prieš derliaus nuẻmimą, siekiant sumažinti nitratų kiekį žalumyninėse daržovėse
}

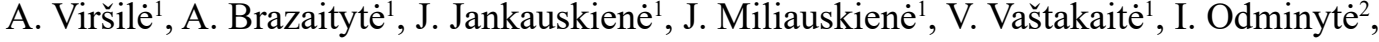 \\ A. Novičkovas ${ }^{3}$, G. Samuolienè ${ }^{1}$ \\ ${ }^{1}$ Lietuvos agrarinių ir miškų mokslų centro Sodininkystės ir daržininkystės institutas \\ ${ }^{2}$ Vytauto Didžiojo universitetas \\ ${ }^{3}$ Vilniaus universiteto Taikomųjų mokslų institutas
}

\section{Santrauka}

Salotinè sultenè (Valerianella locusta L. 'Vit'), trispalvis burnotis (Amaranthus chlorostachys Willd. 'Red Army') ir skrotelinis kopūstas (Brassica rapa var. rosularis L. 'Rozetto F1'), išauginti silpno natūralaus apšvietimo sąlygomis šiltnamyje, 1-7 dienas prieš derliaus nuėmimą buvo papildomai apšviesti $638 \mathrm{~nm}$ bangos ilgio raudoną šviesą skleidžiančių diodų (LED) šviesa. Siekiant išsamiai įvertinti nitratų metabolizmo valdymo galimybes žalumyninėse daržovėse, analizuotas taikyto apšvietimo poveikis nitratų $\left(\mathrm{NO}_{3}\right)$, nitritų $\left(\mathrm{NO}_{2}\right)$, redukuojančių fermentų aktyvumui ir augalo fotosintetiniam aktyvumui įvairių veislių daržovėse. $\mathrm{NO}_{3}, \mathrm{NO}_{2}$, suminis baltymų kiekis ir redukuojančių fermentų aktyvumas priklausė nuo augalo rūšies, apšvietimo trukmès ir jų sąveikos. Reikšmingas $\mathrm{NO}_{3}$ kieko sumažejjimas ir reduktazès aktyvumo padidèjimas nustatytas po trijų dienų trukmès šviesos poveikio. Po apšvietimo buvo nustatytas reikšmingas $\mathrm{NO}_{2}$ ir suminio baltymų kiekio padidèjimas salotinèse sultenèse ir trispalviuose burnočiuose. Skroteliniuose kopūstuose ir salotinèse sultenèse nustatyta vidutinè koreliacija tarp fotosintezès intensyvumo ir $\mathrm{NO}_{3}$ kiekio. Burnočiuose tarp šių rodiklių nustatyta neigiama neesminè koreliacija. Trumpalaikis apšvietimas raudona LED šviesa prieš derliaus nuėmimą gali būti taikomas kaip efektyvus būdas sumažinti nitratų kiekị žalumyninèse daržovėse, išaugintose silpno natūralaus apšvietimo sąlygomis. Tyrimo rezultatai patvirtina reikšmingą ryši tarp augalo fotosintezès bei nitratų apykaitos ir kartu jautrią bei nevienodą skirtingų augalų rūšių fiziologinę reakciją ị taikomą apšvietimą.

Reikšminiai žodžiai: baltymai, fotosintezè, nitratai, nitratų reduktazè, nitritų reduktazè, šviesą skleidžiantys diodai. 